\title{
The Cartel Model and Motions for the Agenda: Israel as a Case Study (2003-2009)
}

\begin{abstract}
Akirav Osnat ${ }^{1}$
We use Cox and McCubbins' cartel theory to investigate the success of Israeli governments in setting their agenda. However, unlike Cox and McCubbins who use legislation as their measure, we use motions for the agenda. We define two stages in setting the agenda by motion: the vote on the floor, indicative of positive agenda power, and the amount of time it takes for a motion passed from the floor to a committee to be actually debated there, indicative of negative agenda power. Findings from the data from two Knesset terms (2003-2009) show that both groups succeed in setting their agenda, but at different stages in the process. [Article copies available for a fee from The Transformative Studies Institute. E-mail address: journal@transformativestudies.org http://www.transformativestudies.org (C2012 by The Transformative Studies Institute. All rights reserved.]
\end{abstract}

KEYWORDS: Cartel Model, Motions for the Agenda, Israel.

During the last four decades, political scientists have posited various theories to explain the functioning of party systems and the evolutionary changes that take place in them. Descriptions of several types of parties have emerged from these theories including the elite party, the mass party, the catch-all party and the cartel model. Cox and McCubbins (2005) used the cartel model, originally devised by Katz and Mair (1995), to advance a theory about American political parties. They tested this theory by using the roll rate to measure the influence of each party. This paper uses the measurement of Cox and McCubbins' cartel theory in

\footnotetext{
${ }^{1}$ Akirav Osnat, Ph.D., is Lecturer and researcher at the Western Galilee College. Address correspondence to: Osnat Akirav, Western Galilee College, Department of Political Science Legislative Studies, 27 Harzit Road, Kfar Vradim, Israel, 25147; e-mail: Osnatak@bezeqint.net.
} 